\title{
E-Short Story in Extensive Reading: A Survey of English Education Department Students
}

\author{
Rini Estiyowati Ikaningrum \\ \{riniestiyowati@untidar.ac.id\} \\ Universitas Tidar, Magelang, Indonesia
}

\begin{abstract}
Extensive reading activity will give freedom to students to select their reading materials since the purpose of extensive reading is reading for pleasure. The kind of reading materials that are used in this research is the e-short story. This research is a survey of 71 students in an extensive reading class in one state university in Central Java. It describes the students' activity of the class by using the e-short story. Besides, the writer wants to represent the factorial analysis of extensive reading class by using e-story in the English education department. This research used factorial analysis in performing the data. From the result, it can be stated that from ten variables and it can be extracted into three variables of the use of technology in reading, simplicity of the e-short story, and lecturer support the use of short stories in extensive reading. The abstract needs to summarize the content of the paper.
\end{abstract}

Keywords: extensive reading, survey, e-short story

\section{INTRODUCTION}

Extensive reading will be focused mainly on students' activities. It is an approach to language education that has shown great promise for foreign language learners to acquire language [1] [2]. Students silently read large quantities of materials. Through extensive reading, students can improve general reading ability, reading speed, and reinforce understanding of vocabulary and grammar along with exposing the learner to new vocabulary and usage [3], [4]. Other advantages of extensive reading include improving learners' attitudes toward the target language, increasing confidence in using the target language, and reducing the fear of reading text [5].

Extensive reading commonly provides reading materials that allow students to choose their reading materials. Appropriate selection of the materials for extended reading is an essential factor to be considered [6]. There are numerous materials for Extensive Reading; one of them is literary. A literary text is a piece of written materials, such as a book, short story, or poem that has the purpose of telling a story or entertaining. Its primary function as a text is usually aesthetic, but it may also contain political messages or beliefs. [7] explains that literary in English teaching will give some benefits such as expanding vocabulary, aiding language acquisition in specified but general ways, giving a feel for the language, developing more fluent reading skills, contributing to cultural and intercultural understanding. Moreover, short 
stories are supposedly mainly, linguistically memorable ( some poetry perhaps qualifies); above all, literature is claimed to be pleasurable.

Extensive reading activity will involve many reading materials in literature. This research considers short stories as reading materials in the extensive reading class. A short story is a piece of prose fiction that typically can be read in one sitting and focuses on a self-contained incident or series of linked incidents, with the intent of evoking a "single effect" or mood. However, there are many exceptions to this [8]. In a short story, its characters and plots may be loosely based on real-life people and real-life events, but they "made-up" than real. As a part of literary, short stories can be in the form of a romance short story, a science-fiction short story, a horror short story, etc.

Integrating computers or/and internet technology in the Foreign language classroom is a challenging activity. Most research findings in the field of ICT reveal promising results about the use of computers and the internet in EFL reading. [2][9] assumes that these technologies can provide "both ESL/EFL teachers and students with virtually boundless uses."

It is challenging to decide what a suitable short story is for university students since the setting is in the English education department. So, in this research, the teacher gives the lists of short stories that are suitable for students in the English education department. But nowadays, in the digital era, students tend to use electronic short stories better than paperback short stories. It happens because of its practicality. Students can read anywhere and anytime by using their computer, laptop, or cellular phone. However, the results of EFL /ESL studies on the use of electronic short stories in extensive reading were various.

There are many studies on the use of short stories as the fundamental source of authentic text. Here are the examples of the previous research. [10] argued that stories presented on phones, tablets, and e-readers now offer an alternative to print books. By using electronic storybooks that contain animated pictures, they can reduce the effort for matching nonverbal information with story language and story comprehension. Another study was from [11]. They examined students' ability to improve their reading comprehension through WebQuests that included instruction on story maps and online story reading for students with learning disabilities. In conclusion, students found the WebQuests to be informative and helped them with their reading. From those examples, they suggest that learners and teachers will have benefit from the flexibility to use the online reading system, e-book, or e-short story. Therefore, the present study attempted to describe extensive reading activity using e-short stories in the English education department.

\section{METHOD}

This research was conducted in an extensive reading class in the English education department from a new state university in Central Java. It is survey research that gathers information from a sample of students that can be generalized to a larger population. The writer uses a descriptive survey because she tried to describe the existing condition in the extensive reading class. The questionnaire used in this research was adapted from [6]. The questionnaire is used to know the real responses that are stated by students about the use of eshort stories in the extensive reading class. Seventy-one students participated in the survey. Hopefully, the result will represent all students in the extensive reading class.

One of the primary purposes of the study is to reduce the number of variables. The questionnaire collected feedback from these students on their perception of the use of technology in extensive reading. Besides, the writer wants to know that the use of the e-short story is easy for students. Therefore the lecturer supports the use of short stories in extensive 
reading. Factor analysis is an analytical tool for deriving constructs or latent variables or factors from a set of items [7] and is a suitable statistical approach that can identify groups of similar items to represent a set of measures (variables). Hence, relationships between the objects can be modeled [8]. Thus, factor analysis was used to extract new variables to provide a better understanding of the data.

\section{RESULT AND DISCUSSION}

From the factor analysis, the writer was able to select relevant items to be included in a measure to identify the use of an e-short story in the extensive reading class. According to [12], "factor analysis requires two stages: factor extraction and factor rotation." Factor extraction uses the principal component analysis (PCA) to determine the number of factors that underlie a set of measured variables. Then to make the factors more interpretable, factor rotation is used to statistically manipulate the results to make a final decision on the number of underlying factors.

The purpose of PCA is to define the components under which the questionnaire items were loaded [3]. Before the PCA, the Kaiser-Meyer-Olkin (KMO) test was used to test the adequacy of the sample size for factor analysis, and the KMO test has shown a value of 0.706 ; this verifies that the number of samples is sufficient. Moreover, the Bartlett test is used to test the presence of correlations among the variables, where adequate relationships exist among the variables if there is a significant Bartlett's test of sphericity. The results, as shown in Table 1 below, have disclosed that Bartlett's test of sphericity is significant, with chi-square $=279.813, \mathrm{df}=45$, and significance $=0.000$.

Tabel 1. KMO and Bartlett's Test

\begin{tabular}{lccc}
\hline Kaiser-Meyer Olkin $\quad$ Measure & of & Sampling & \\
Adequacy. & & Apprx.ChiSquare & 279.813 \\
\hline Bartlett's Test of Sphericity & Df & 45 \\
& Sig. & .000 \\
& & & \\
\hline
\end{tabular}

The subsequent analysis is Extraction Method that is Principal Component Analysis. From the table of commonalities, the variable 'lecturer chooses the appropriate genre of short story' is 0.549 . It means that $54.9 \%$ variances from that variable can be explained by the form factor. From variable 'reading short story helps me improve my reading skill' is 0.633 , that means $63.3 \%$ variances from that variable can be explained by the form factor. It happens in all other variables; the smallest communalities values the weakest correlation among the form factor.

Based on the previous description, it can be stated that all the questions given by the lecturer are appropriate to students. The table shows that most of the students give positive responses; for example, they like using the e-short story in extensive reading. From the result, only a small number of students give negative responses about the use of the e-short stories in the extensive reading activity. It implies that the majority of the students who enjoy the material in extensive reading using e-short stories are better than using printed materials since the use of e-short stories will be more practical for most of the students. Table two below shows the complete result of students' responses from the questionnaire. 
Tabel 2. Communalities

\begin{tabular}{lll}
\hline & Initial & Extraction \\
\hline Lecturer chooses the appropriate genre of the short story & 1.000 & .549 \\
Reading a short story helps me improve my reading skill & 1.000 & .633 \\
I can use my mobile phone to read a short story & 1.000 & .656 \\
I can read short story anywhere & 1.000 & .819 \\
I can read the short story anytime & 1.000 & .837 \\
I feel easy to read the e-short story & 1.000 & .641 \\
The Internet provides a large library of short stories & 1.000 & .628 \\
I am easy to search e-short stor & 1.000 & .760 \\
ies & 1.000 & .657 \\
I can read and understand one short story in a week & 1.000 & .623 \\
Lecturer asks me to make a summary/review of a short & & \\
story & & \\
\end{tabular}

From the above table of communalities, the result shows that the first question, "Lecturer chooses the appropriate genre of the short story," is the weakest correlation value among the form. While the most reliable correlation value is " I can read the short story anytime."

The subsequent analysis is for pattern matrix. In this section, the variables are reduced from ten numbers into three numbers. Here is the result of the pattern matrix in this following table 3 .

Table 3. Pattern Matrix

\begin{tabular}{lccc}
\hline & Component & \\
\hline & 1 & 2 & 3 \\
I can read the short story anytime & .915 & & \\
I can read short story anywhere & .904 & \\
I can use my mobile phone to read a short story & .814 & & \\
I am easy to search e-short story. & & .864 & \\
The Internet provides an extensive library of short stories & .830 & \\
I can read and understand one short story in a week & .723 & \\
I feel comfortable to read an e-short story & .521 & .781 \\
Lecturer chooses the appropriate genre of a short story & & .745 \\
Lecturer asks me to make a summary/review of a short & & & .674 \\
story & & & \\
Reading a short story helps me improve my reading skill & & & \\
\end{tabular}

From the pattern matrix above, it can be stated that for the ten variables become into three variables only. They are the use of technology in reading, simplicity of the e-short story, and lecturer support on the use of e-short stories in extensive reading. Hence the three variables become the main factors that affect students in the extensive reading activity.

The following explanation is about the component correlation matrix that shows the correlation among the components. The next table shows the detail information. 
Table 5. Component Correlation Matrix

\begin{tabular}{lrrr}
\hline Component & 1 & 2 & 3 \\
\hline 1 & 1.000 & .283 & .187 \\
& .283 & 1.000 & .353 \\
2 & .187 & .353 & 1.000 \\
\hline
\end{tabular}

The table above indicates that the rotation done is an oblique rotation, if an orthogonal rotation had been done (like the varimax rotation shown above), this table would not appear in the output because the correlations between the factors are set to 0 . Here, you can see that the factors are highly correlated.

\section{CONCLUSION}

The study shows the significant benefits the technology-enhanced extensive reading classroom can offer students and teachers, particularly in helping the former introduce changes in the teaching of reading and in engaging the latter in the fruitful skill of extensive reading. From the result of the questionnaire, it can be stated that students tend to use a computer or other gadgets to help them finding an e-short story from the internet, which is asked by the lecturer. Because of its practicality, students tend to use a mobile phone to read the e-short story. Students can save their time and money to do the assignment from the lecturer in extensive reading since they do not need to have an expensive paperback short story. We hope the present study will help both teachers and students step toward innovation in the reading classroom and cooperate in introducing ICT in the extensive reading classroom.

This exploratory study has extracted ten factors which have significant contribution in performing students' extensive reading and the use of electronic novel. These ten factors can be used to explain the preferences and needs of the use of electronic books in the extensive reading class. These factors could be considered by teachers/lecturers when designing extensive reading materials by using an electronic short story.

\section{References}

[1] K. O. Ugwuanyi, "Communicative performance in the written discourse of undergraduate students: What can literature offer?," Bellaterra J. Teach. Learn. Lang. Lit., vol. 10, no. 3, pp. 66-81, Aug. 2017.

[2] J. Day, Richard and Bamford, “Top Ten Principles for Teaching Extensive Reading1," Read. a Foreign Lang., vol. 14, no. 2, pp. 136-141, 2002.

[3] H. Tanaka and P. Stapleton, "Increasing Reading Input in Japanese High School Efl Classrooms: an Empirical Study Exploring the Efficacy of Extensive Reading," Read. Matrix, vol. 7, no. 1, pp. 115-131, 2007.

[4] S. H. Teoha, A. C. Koo, and P. Singh, "Extracting factors for students' motivation in studying mathematics," Int. J. Math. Educ. Sci. Technol., vol. 41, no. 6, pp. 711-724, 2010 .

[5] J. Yamashita, "Effects of extensive reading on reading attitudes in a foreign language," Read. a Foreign Lang., vol. 25, no. 2, pp. 248-263, 2013.

[6] S. Ghiabi, "Investigation of the effect of using a novel as an extensive reading on students' attitudes and reading ability," Int. J. Appl. Linguist. English Lit., vol. 3, no. 
4, pp. 55-64, 2014.

[7] H. K. Kim and D. Rissel, "Instructors' integration of computer technology: Examining the role of interaction," Foreign Lang. Ann., vol. 41, no. 1, pp. 61-80, 2008.

[8] A. Field, Discovering Statistics using SPSS. 2009.

[9] G. Hall, Literature in Language Education. Research and Practice in Applied Linguistics. 2005.

[10] A. G. Bus, Z. K. Takacs, and C. A. T. Kegel, "Affordances and limitations of electronic storybooks for young children's emergent literacy," Dev. Rev., vol. 35, pp. 79-97, 2015.

[11] M. E. Stetter and M. T. Hughes, "Using webquests to promote reading comprehension for students with learning disabilities," Int. J. Spec. Educ., vol. 32, no. 3, pp. 608-617, 2017.

[12] and J. B. U. Tabachnick, Barbara G., Linda S. Fidell, Using multivariate statistics, vol. 28 , no. 8. 2007. 